TREE-RING RESEARCH, Vol. 61(1), 2005, pp. 3-19

\title{
SEASONAL GROWTH CHARACTERISTICS OF KAURI
}

\author{
ANTHONY FOWLER*, ANDREW LORREY, and PETER CROSSLEY
}

The University of Auckland, Private Bag 92019

School of Geography and Environmental Science

Auckland, New Zealand

\begin{abstract}
Considerable research has occurred in recent years to build Agathis australis (D. Don) Lindley (kauri) tree-ring chronologies for paleoclimate applications and to identify statistical relationships between kauri tree rings and climate. This paper reports on a multi-year study of the seasonal growth of kauri, designed to assist in the interpretation of identified statistical relationships, and to determine if kauri's seasonal growth characteristics are dependent on tree size. To achieve this, 43 kauri (0.09-2.00 m diameter) at Huapai Scientific Reserve were fitted with vernier bands to measure circumference change over 3-4 growing seasons. Absolute $(\mathrm{mm})$ and relative (proportion of total ring) monthly growth rates were calculated for each tree and statistics characterizing the timing of growth were calculated (e.g. date corresponding to 50\% of growth). Tree size-related differences were assessed by splitting the data into three subsets based on size, then comparing the monthly growth rates and growth timing statistics for the subsets. The growth timing statistics were also correlated with tree diameter. A key finding is the strong dominance of spring growth, with October and November alone accounting for 38-50\% of the total ring width. This result is consistent across age cohorts, although the largest trees tended to peak in November, rather than October. This indicates that kauri tree rings are likely to have value in terms of reconstructing spring conditions; consistent with reported statistical relationships between kauri tree rings and the El Niño-Southern Oscillation phenomenon. High inter-tree variance in growth rates characterized the results, but little of this variance was accounted for by tree size. Although relationships between tree size and growth characteristics were generally weak and inconsistent, they are considered sufficient to warrant a precautionary approach in the development of tree-ring chronologies for climate reconstruction purposes.
\end{abstract}

Keywords: Tree rings, dendrochronology, dendrometer bands, kauri, Agathis australis, New Zealand.

\section{INTRODUCTION}

Considerable research has occurred in recent years on Agathis australis (D. Don) Lindley (kauri) tree rings. Fowler et al. (2004) recently confirmed the validity of building kauri master chronologies by pooling samples from almost anywhere in kauri's natural growth range. Their statistical assessment of the quality of such master chronologies showed that high quality multi-century tree-ring time series can be built. Subsequent work has linked living and sub-fossil kauri, resulting in a continuous kauri tree-ring record approaching 4000 years. The net result is a high quality multi-century record and a lower quality (caused by lower sample depth) multi-millennial record available for paleoclimate reconstruction.

\footnotetext{
*Corresponding Author: a.fowler@auckland.ac.nz
}

The potential of kauri for paleoclimate reconstruction was most recently demonstrated by Buckley et al. (2000) and Fowler et al. (2000). In both cases, correlation analysis identified the relationship between kauri growth and climate experienced by the trees prior to, during, and immediately after the growing season. Buckley et al. (2000) identified negative correlations between kauri growth and both rainfall and temperature during the growing season, but positive correlations at lags of 2-4 years. Based on these results, Fowler et al. (2000) deduced a potential link to the El Niño-Southern Oscillation phenomenon (ENSO), and subsequently identified a much stronger relationship between kauri growth and ENSO than with local temperature and precipitation.

Climate reconstruction from tree rings entails the derivation of transfer functions relating indices 
of tree growth to climate. This is essentially a statistical exercise, typically involving regression of climate variables against one or more tree-ring time series. Selection of appropriate climate variables and the time periods to which they relate (e.g. annual temperature, summer rainfall) is usefully informed by response function analyses. Also useful, but often lacking, is knowledge of the seasonal growth characteristics of the species, such as the timing of the growth season and when growth peaks. For example, knowing when in the growing season the majority of the growth ring is laid down would assist in identifying relationships between climate and growth.

This study was undertaken to investigate the seasonal growth characteristics of kauri in a natural forest environment by monitoring the growth of many trees for several years. It was anticipated that this would provide insight into kauri-climate statistical relationships (Buckley et al. 2000; Fowler et al. 2000) and inform subsequent construction of paleoclimate transfer functions. A second aim was to determine if these seasonal growth characteristics are dependent on tree size/age. This is important in terms of the uniformitarianism assumption that underpins paleoclimate research because the kauri-climate transfer functions used to reconstruct past climate are derived for old trees, but are assumed to also apply to young trees.

The study was undertaken at Huapai Scientific Reserve (grid reference: NZMS 260 Q11 434884), approximately $6.75 \mathrm{~km}$ from the west coast, in the lower northern foothills of the Waitakere Ranges, NW of Auckland, and about $90 \mathrm{~m}$ above mean sea level. The specific site was centered on a northorientated headwater catchment within the reserve (Figure 1). The western ridge of this catchment has several large kauri ( $>1 \mathrm{~m}$ diameter at breast height (DBH)), some over 500 years old (Fowler and Boswijk 2001). The eastern ridge is also kauridominated, although only five trees are larger than $1 \mathrm{~m} \mathrm{DBH}$. The site was chosen because of the wide range of tree sizes within a few hundred meters and the practical benefits associated with proximity to Auckland. Huapai is also conveniently near the middle of kauri's natural growth range. Additional details of Huapai Scientific Reserve were given in Fowler and Boswijk (2001).

\section{METHODS}

\section{Instrumentation and Data Collection}

Spring-tensioned flexible stainless steel bands with attached vernier scales (Figure 2) were installed on 43 kauri at Huapai in 1996 and 1997 (Table 1). Tree sizes ranged from 0.09 to $2.0 \mathrm{~m}$ $\mathrm{DBH}$, with 16 less than $0.3 \mathrm{~m} \mathrm{DBH}, 12$ larger than $1.1 \mathrm{~m}$, and the remaining 15 of intermediate size. All readily-accessible trees above $0.65 \mathrm{~m} \mathrm{DBH}$ on or near the ridge tops were banded. These are the labeled crowns shown in Figure 1, except for two smaller trees $(1208,1217)$ at the southern (higher) end of the west ridge. The balance of the sample was from the northern end of the east ridge.

The stainless steel bands used were $10 \mathrm{~mm}$ wide by $0.1 \mathrm{~mm}$-thick flexible "float tape" (designed for suspension of floats and counterweights on chart recorders used to monitor water levels). They were installed around the trees with an underlying and overlapping plastic sheet, designed to reduce friction and prevent sticking of the bands by exuded kauri gum. Each was held in place by the tension of the spring and prevented from slipping by stainless steel sewing pins tacked into the bark immediately below the band, at intervals of about $0.5 \mathrm{~m}$. Verniers were custom-printed $0.13 \mathrm{~mm}$ thick aluminum sticky labels with a nominal precision of $0.01 \mathrm{~mm}$.

It took about one hour to complete a data collection circuit of the trees. This was almost always done mid-morning and in the same order. The verniers were usually read to the nearest $0.02 \mathrm{~mm}$ and all readings were made without reference to prior observations. Intervals between measurements varied from a few days to several weeks, but with at least one measurement in each month. Tree circumferences were monitored from the various dates the bands were installed. All trees were monitored from late-1997 to mid-2000, giving three complete growing seasons (1997-1998, 19981999, 1999-2000). However, the beginning of the 1997-1998 season was incomplete for some trees, including nine of the 12 trees larger than $1.1 \mathrm{~m}$ DBH.

\section{Error Identification and Correction}

The vernier band method has several possible sources of error (Table 2). Errors 1-6 were rela- 


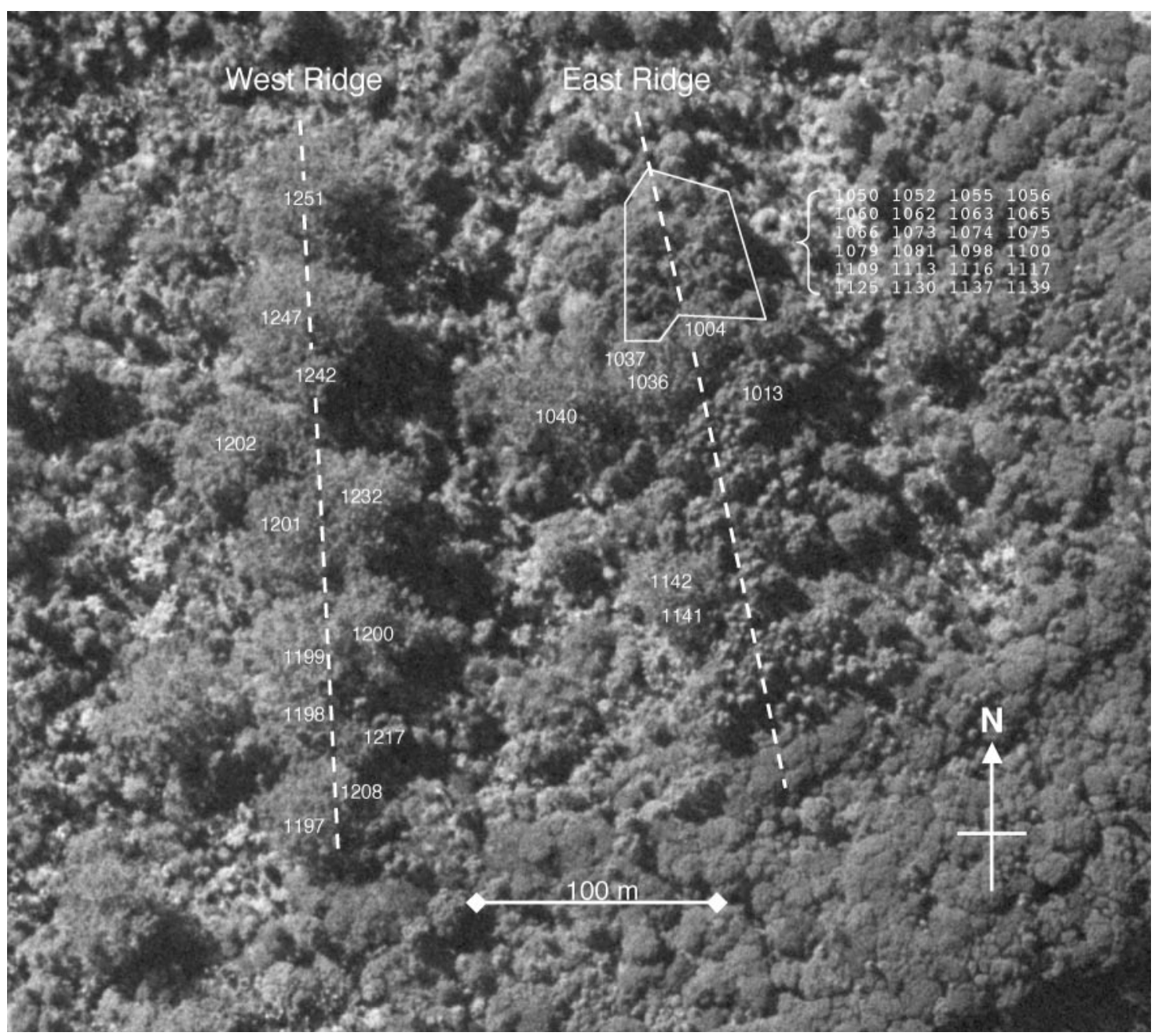

Figure 1. Aerial photo of the Huapai study site (flown March 24, 2000). All monitored trees on the west ridge, and all trees above $0.65 \mathrm{~m} \mathrm{DBH}$ on the east ridge, are labeled by their identification tags (Table 1). The remaining 24 trees are within the polygon at the northern end of the east ridge.

tively minor, intermittent, and affected a few trees at any one time. Affected data were corrected and suspect data were deleted. Missing data for up to three consecutive observations was infilled by assuming that the relative circumference increase of the tree before and after the missing period was representative of the relative increase for the missing period. Specifically, the sum of circumference changes recorded for two dates before and two dates after the missing data was divided by the median of sums across all trees with non-missing data for those four dates. This ratio was then multiplied by the median of the same non-missing trees for each of the missing data dates. Thirteen observations $(<0.5 \%)$ were infilled in this way.

Error 7 (lifting bark) was more prevalent and insidious. Kauri sheds outer layers of bark as flakes, which vary in size, depending on tree size. Flakes from mature trees are often tens of $\mathrm{cm}$ wide, can exceed $10 \mathrm{~mm}$ thickness, and take several years to detach, often lifting from the trunk on one side. Flaking pushed the vernier bands outwards, causing an increase in tree circumference. Obvious flakes were removed prior to installing the vernier bands and periodic inspection undertaken to identify new flakes. Where possible, these 


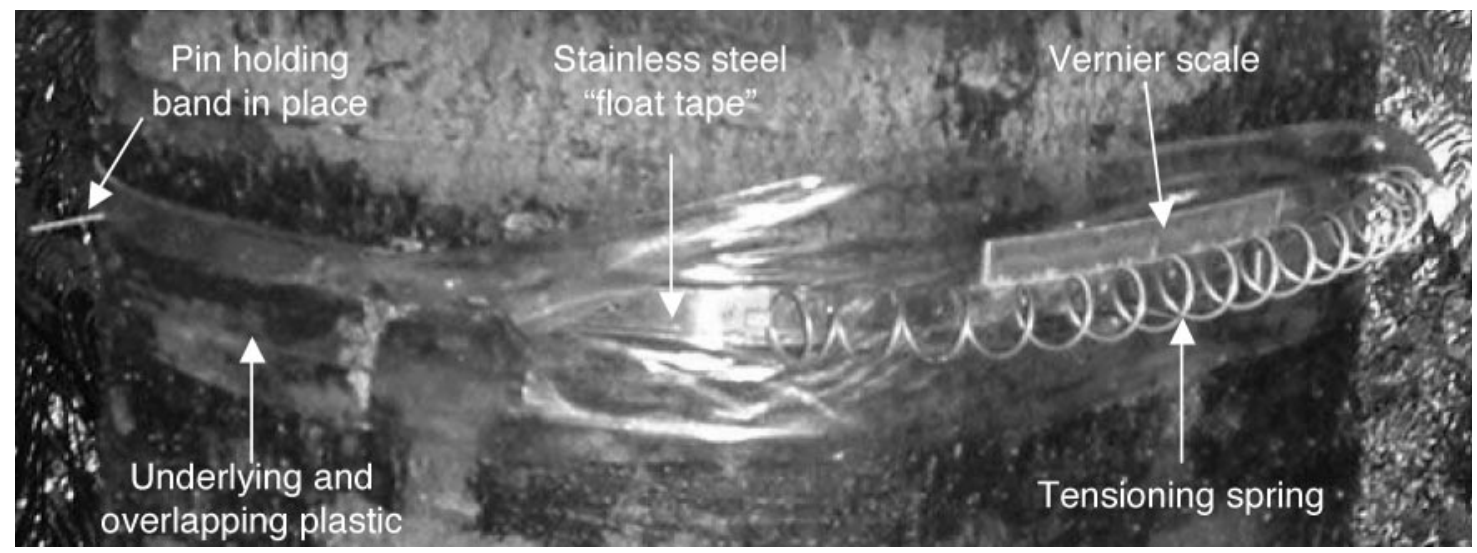

Figure 2. Vernier band setup.

were removed, and the data corrected. However, there is certainly residual error associated with the early stages of flaking where no external evidence (cracking) was observed, or the flake was not sufficiently developed to pry it loose. The magnitude of the residual error is not quantified and introduces a systematic bias of apparent exaggerated growth.

Error 8 (bark expansion and contraction) refers to non-growth related circumference changes as bark wets and dries. This includes bark wetting and drying cycles associated with storms and the annual cycle. Fowler (1984) showed that kauri bark flakes expand radially by about $3 \%$ when saturated. Assuming an initially dry tree, $10 \mathrm{~mm}$ of bark subject to moisture-related variation, and subsequent complete bark saturation, the circumference increase would be $1.9 \mathrm{~mm}$. This is a very large potential error, comparable in size to maximum recorded monthly growth rates. However, storm-related error is thought to be minor. The maximum potential could only be achieved during summer storms, and even surface wetness was rarely observed at this time of year (and then usually only on the windward side of trees well above the bands). More problematic is a likely systematic bias in circumference measurements coupled to the annual cycle. As the Auckland region moves into its cool and wet winter, outer bark layers will accumulate moisture. This probably begins around April (monthly mean precipitation (P) exceeds potential evaporation (PE)) and may peak in June and July when P exceeds PE by more than a factor of four and mean relative humidity climbs to $80 \%$ (Fowler 1999). The most likely impact on vernier measurements is non-growth related circumference increase in winter. The reverse situation is likely from around October as moisture deficit conditions set in. The absolute error is likely to be similar, but its relative importance will be reduced by high growth rates at this time of year. No attempt was made to correct for this error.

Error 9 relates to variation of water content in trees with changes in evaporative demand and soil water status. During periods of high transpiration and/or low soil water content, trees may lose water content and shrink (Fritts 1976). Rehydration, with associated expansion, occurs when transpiration declines (especially at night) or soil water content increases sufficiently to meet supply (through lowering resistances to water movement to the roots). Observations were made during the morning to minimize non-growth-related shrinkage and expansion, but no explicit attempt was made to correct the data.

Error 10 refers to the swelling of cells in early spring related to the breaking of dormancy (Schweingruber 1996). Increasing cell turgor immediately prior to growth will cause early season trunk expansion that is not a result of new xylem formation. Because such trunk expansion would be indistinguishable in the vernier observations from first xylem formation, no correction for it could reasonably be made. There will be a corresponding opposite error as cells lose turgor in winter. However, this is less problematic, because associated 
Table 1. Details of banded trees and dates when short cores were taken.

\begin{tabular}{|c|c|c|c|c|c|c|c|c|}
\hline \multirow[b]{2}{*}{ Tree ID } & \multirow{2}{*}{$\begin{array}{c}\mathrm{DBH}^{1} \\
(\mathrm{~m})\end{array}$} & \multirow{2}{*}{$\begin{array}{l}\text { Size Class } \\
(\mathrm{L} / \mathrm{M} / \mathrm{S})^{2}\end{array}$} & \multirow{2}{*}{$\begin{array}{l}\text { Ridge } \\
(E / W)\end{array}$} & \multirow{2}{*}{$\begin{array}{l}\text { Vernier } \\
\text { Start Date }\end{array}$} & \multicolumn{4}{|c|}{ Coring Dates } \\
\hline & & & & & 9.24 .2002 & 12.11 .2002 & 3.7 .2003 & 6.23 .2003 \\
\hline 1004 & 1.04 & M & E & 10.13 .96 & & & $\mathrm{X}$ & $\mathrm{X}$ \\
\hline 1013 & 0.69 & M & E & 10.13 .96 & & & $X$ & $X$ \\
\hline 1036 & 1.26 & $\mathrm{~L}$ & E & 11.12 .96 & & & $X$ & $\mathrm{X}$ \\
\hline 1037 & 0.91 & M & $\mathrm{E}$ & 10.13 .96 & & $\mathrm{X}$ & & $X$ \\
\hline 1040 & 1.68 & $\mathrm{~L}$ & $\mathrm{E}$ & 10.13 .96 & & $\mathrm{X}$ & & $X$ \\
\hline 1050 & 0.35 & M & $\mathrm{E}$ & 10.23 .96 & $\mathrm{X}$ & & & $\mathrm{X}$ \\
\hline 1052 & 0.62 & M & $\mathrm{E}$ & 10.13 .96 & $\mathrm{X}$ & & & $\mathrm{X}$ \\
\hline 1055 & 0.18 & S & $\mathrm{E}$ & 10.23 .96 & & & $X$ & $X$ \\
\hline 1056 & 0.23 & $\mathrm{~S}$ & E & 10.23 .96 & & & $\mathrm{X}$ & $X$ \\
\hline 1060 & 0.10 & S & E & 11.12 .96 & & $X$ & & $\mathrm{X}$ \\
\hline 1062 & 0.24 & S & E & 11.12 .96 & $\mathrm{X}$ & & & $X$ \\
\hline 1063 & 0.14 & S & E & 11.12 .96 & & $\mathrm{X}$ & & $\mathrm{X}$ \\
\hline 1065 & 0.30 & M & $\mathrm{E}$ & 11.12 .96 & & $\mathrm{X}$ & & $\mathrm{X}$ \\
\hline 1066 & 0.18 & S & $\mathrm{E}$ & 11.12 .96 & & $\mathrm{X}$ & & $X$ \\
\hline 1073 & 0.15 & S & $\mathrm{E}$ & 10.23 .96 & & $\mathrm{X}$ & & $\mathrm{X}$ \\
\hline 1074 & 0.11 & $\mathrm{~S}$ & $\mathrm{E}$ & 10.23 .96 & & $\mathrm{X}$ & & $\mathrm{X}$ \\
\hline 1075 & 0.20 & $\mathrm{~S}$ & $\mathrm{E}$ & 10.23 .96 & $\mathrm{X}$ & & & $\mathrm{X}$ \\
\hline 1079 & 0.23 & $\mathrm{~S}$ & $\mathrm{E}$ & 11.12 .96 & & $X$ & & $\mathrm{X}$ \\
\hline 1081 & 0.09 & $\mathrm{~S}$ & $\mathrm{E}$ & 05.10 .96 & & $\mathrm{X}$ & & $\mathrm{X}$ \\
\hline 1098 & 0.49 & M & $\mathrm{E}$ & 10.13 .96 & & & $\mathrm{X}$ & $X$ \\
\hline 1100 & 0.38 & M & $\mathrm{E}$ & 10.13 .96 & & $X$ & & $X$ \\
\hline 1109 & 0.20 & S & $\mathrm{E}$ & 10.23 .96 & $X$ & & & $\mathrm{X}$ \\
\hline 1113 & 0.22 & $S$ & $\mathrm{E}$ & 11.12 .96 & $X$ & & & $X$ \\
\hline 1116 & 0.32 & M & $\mathrm{E}$ & 10.13 .96 & & $X$ & & $\mathrm{X}$ \\
\hline 1117 & 0.14 & S & $\mathrm{E}$ & 10.23 .96 & & $X$ & & $X$ \\
\hline 1125 & 0.31 & M & $\mathrm{E}$ & 10.13 .96 & & $\mathrm{X}$ & & $\mathrm{X}$ \\
\hline 1130 & 0.18 & $S$ & $\mathrm{E}$ & 10.23 .96 & & & $\mathrm{X}$ & $\mathrm{X}$ \\
\hline 1137 & 0.30 & M & $\mathrm{E}$ & 10.13 .96 & & $\mathrm{X}$ & & $X$ \\
\hline 1139 & 0.24 & $\mathrm{~S}$ & $\mathrm{E}$ & 10.23 .96 & & & $\mathrm{X}$ & $\mathrm{X}$ \\
\hline 1141 & 1.14 & $\mathrm{~L}$ & $\mathrm{E}$ & 11.12 .96 & $X$ & & & $\mathrm{X}$ \\
\hline 1142 & 0.95 & M & $\mathrm{E}$ & 11.12 .96 & $X$ & & & $X$ \\
\hline 1197 & 1.29 & $\mathrm{~L}$ & W & 10.24 .97 & $\mathrm{X}$ & & & $\mathrm{X}$ \\
\hline 1198 & 0.81 & M & W & 10.24 .97 & & $X$ & & $\mathrm{X}$ \\
\hline 1199 & 1.56 & $\mathrm{~L}$ & W & 10.24 .97 & $X$ & & & $\mathrm{X}$ \\
\hline 1200 & 1.35 & $\mathrm{~L}$ & W & 10.24 .97 & & & $X$ & $X$ \\
\hline 1201 & 2.00 & $\mathrm{~L}$ & W & 10.24 .97 & & $X$ & & $X$ \\
\hline 1202 & 1.82 & $\mathrm{~L}$ & W & 12.06 .97 & & & $\mathrm{X}$ & $\mathrm{X}$ \\
\hline 1208 & 0.64 & M & W & 10.24 .97 & $\mathrm{X}$ & & & $\mathrm{X}$ \\
\hline 1217 & 0.38 & M & W & 10.24 .97 & & & $\mathrm{X}$ & $\mathrm{X}$ \\
\hline 1232 & 1.81 & $\mathrm{~L}$ & W & 10.24 .97 & & & $\mathrm{X}$ & $\mathrm{X}$ \\
\hline 1242 & 1.14 & $\mathrm{~L}$ & W & 12.06 .97 & & & $\mathrm{X}$ & $\mathrm{X}$ \\
\hline 1247 & 1.99 & $\mathrm{~L}$ & W & 12.06 .97 & $X$ & & & $X$ \\
\hline 1251 & 1.89 & $\mathrm{~L}$ & W & 12.06 .97 & & $X$ & & $X$ \\
\hline
\end{tabular}

${ }^{1} \mathrm{DBH}$ measured when vernier bands installed.

${ }^{2}$ Three-way size class split $(\mathrm{L}=$ large, $\mathrm{M}=$ middle, $\mathrm{S}=$ small $) . \mathrm{S}<0.3 \mathrm{~m} \leq \mathrm{M} \leq 1.1 \mathrm{~m} \leq \mathrm{L}$.

circumference reduction will not be confused with xylem changes.

Errors 11 and 12 concern apparent variations in circumference caused by change in air temperature and the different thermal expansion characteristics of stainless steel and living wood. Expansion/contraction of both would follow the annual cycle, but with the bands exhibiting greater variability be- 
Table 2. Vernier band sources of data error and error resolution.

\begin{tabular}{|c|c|c|c|c|c|}
\hline Error & Cause & Frequence & $\begin{array}{c}\text { Impact on } \\
\text { Measurement }\end{array}$ & $\begin{array}{l}\text { Problem } \\
\text { Resolution }\end{array}$ & Residual Error \\
\hline 1. Sticking band & $\begin{array}{l}\text { Gum "gluing" } \\
\text { band to tree }\end{array}$ & $\begin{array}{l}\text { Rare \& only in } \\
1 \text { st year }\end{array}$ & $\begin{array}{l}\text { Periods of no ap- } \\
\text { parent growth } \\
\text { then sudden re- } \\
\text { lease }\end{array}$ & $\begin{array}{l}\text { Band pried loose } \\
\& \text { data deleted }\end{array}$ & $\begin{array}{l}\text { Minor cases possibly } \\
\text { unobserved }\end{array}$ \\
\hline $\begin{array}{l}\text { 2. Re-tensioning } \\
\text { springs }\end{array}$ & $\begin{array}{l}\text { Increasing } \\
\text { spring tension } \\
\text { as trees grew }\end{array}$ & Most trees once & $\begin{array}{l}\text { Instantaneous shift } \\
\text { in vernier values } \\
\text { (at time of re- } \\
\text { tensioning) }\end{array}$ & $\begin{array}{l}\text { Before \& after } \\
\text { measurements } \\
\text { taken \& data } \\
\text { corrected }\end{array}$ & $\begin{array}{l}\text { Post-disturbance re-tensioning } \\
\text { of the band may have } \\
\text { caused under-measurement } \\
\text { in subsequent weeks }\end{array}$ \\
\hline 3. Disturbance & $\begin{array}{l}\text { Interference by } \\
\text { vistors }\end{array}$ & Rare & Unknown & $\begin{array}{l}\text { Band adjusted \& } \\
\text { questionable } \\
\text { data deleted }\end{array}$ & Ditto above \\
\hline $\begin{array}{l}\text { 4. Growth beyond } \\
\text { vernier limits }\end{array}$ & $\begin{array}{l}\text { Normal tree } \\
\text { growth }\end{array}$ & Rare & $\begin{array}{l}\text { Instantaneous shift } \\
\text { in vernier values } \\
\text { at time of re- } \\
\text { tensioning }\end{array}$ & $\begin{array}{l}\text { Verniers replaced } \\
\text { \& data corrected } \\
\text { using before \& } \\
\text { after measure- } \\
\text { ments }\end{array}$ & Ditto above \\
\hline $\begin{array}{l}\text { 5. Vernier re-align- } \\
\text { ment }\end{array}$ & $\begin{array}{l}\text { End of bands } \\
\text { misaligned \& } \\
\text { without } \\
\text { guides }\end{array}$ & $\begin{array}{l}\text { Never for most } \\
\text { trees but } \\
\text { common for } \\
\text { others }\end{array}$ & Loss of precision & $\begin{array}{l}\text { Adjustment of ver- } \\
\text { nier alignment } \\
\& \text { installation of } \\
\text { guide pins }\end{array}$ & $\begin{array}{l}\text { Slight loss of quality (addition- } \\
\text { al noise) }\end{array}$ \\
\hline $\begin{array}{l}\text { 6. Change of ob- } \\
\text { server }\end{array}$ & $\begin{array}{l}\text { Use of } 2 \text { nd ob- } \\
\text { server }\end{array}$ & $\begin{array}{l}\text { Occasional in } \\
1998 \text { only }\end{array}$ & Unknown & None & $\begin{array}{l}\text { Possible systematic bias, but } \\
\text { probably minor (based on } \\
\text { spot checking) }\end{array}$ \\
\hline 7. Lifting band & $\begin{array}{l}\text { Outer layers of } \\
\text { bark flaking } \\
\& \text { pushing } \\
\text { the band out }\end{array}$ & $\begin{array}{l}\text { Common with } \\
\text { larger trees, } \\
\text { esp. in year } 3\end{array}$ & $\begin{array}{l}\text { Exaggerated appar- } \\
\quad \text { ent growth }\end{array}$ & $\begin{array}{l}\text { Removal of bark } \\
\text { flakes \& data } \\
\text { deleted or sub- } \\
\text { jectively cor- } \\
\text { rected }\end{array}$ & $\begin{array}{l}\text { Some cases possibly unob- } \\
\text { served }\end{array}$ \\
\hline $\begin{array}{l}\text { 8. Bark expansion } \\
\& \text { contraction }\end{array}$ & $\begin{array}{l}\text { Wetting and } \\
\text { drying of } \\
\text { bark }\end{array}$ & $\begin{array}{l}\text { Ubiquitous sea- } \\
\text { sonal \& ma- } \\
\text { jor storms }\end{array}$ & $\begin{array}{l}\text { Seasonal \& storm } \\
\text { event bias }\end{array}$ & None & $\begin{array}{l}\text { Ubiquitous non-growth related } \\
\text { winter increase in circumfer- } \\
\text { ence \& spring decrease (as } \\
\text { bark dries) }\end{array}$ \\
\hline $\begin{array}{l}\text { 9. Trunk expansion } \\
\& \text { contraction }\end{array}$ & $\begin{array}{l}\text { Transpiration } \\
\text { water stress }\end{array}$ & $\begin{array}{l}\text { Ubiquitous sea- } \\
\text { sonal \& diur- } \\
\text { nal }\end{array}$ & $\begin{array}{l}\text { Seasonal \& diurnal } \\
\text { bias }\end{array}$ & None & $\begin{array}{l}\text { Likely inconsistent (rainfall- } \\
\text { dependent) seasonal bias } \\
\text { (typically late-summer } \\
\text { shrinkage, then autumn ex- } \\
\text { pansion) }\end{array}$ \\
\hline $\begin{array}{l}\text { 10. Trunk expansion } \\
\& \text { contraction }\end{array}$ & $\begin{array}{l}\text { Change in cell } \\
\text { turgor related } \\
\text { to dormancy }\end{array}$ & $\begin{array}{l}\text { Ubiquitous sea- } \\
\text { sonal }\end{array}$ & Seasonal bias & None & $\begin{array}{l}\text { Ubiquitous early season cir- } \\
\text { cumference increase and } \\
\text { winter decrease }\end{array}$ \\
\hline $\begin{array}{l}\text { 11. Trunk expansion } \\
\& \text { contraction }\end{array}$ & $\begin{array}{l}\text { Thermal expan- } \\
\text { sion charac- } \\
\text { teristics of } \\
\text { living wood }\end{array}$ & $\begin{array}{l}\text { Common sea- } \\
\text { sonal \& diur- } \\
\text { nal }\end{array}$ & $\begin{array}{l}\text { Seasonal \& possi- } \\
\text { ble diurnal bias }\end{array}$ & None & $\begin{array}{l}\text { Ubiquitous non-growth related } \\
\text { spring to mid-summer in- } \\
\text { crease in circumference, } \\
\text { then decrease from mid- } \\
\text { summer to autumn }\end{array}$ \\
\hline $\begin{array}{l}\text { 12. Vernier band } \\
\text { contraction \& } \\
\text { expansion }\end{array}$ & $\begin{array}{l}\text { Thermal expan- } \\
\text { sion charac- } \\
\text { teristics of } \\
\text { stainless steel }\end{array}$ & $\begin{array}{l}\text { Common sea- } \\
\text { sonal \& diur- } \\
\text { nal }\end{array}$ & $\begin{array}{l}\text { Seasonal \& diurnal } \\
\text { bias }\end{array}$ & $\begin{array}{l}\text { Corrected based } \\
\text { on thermal ex- } \\
\text { pansion coeffi- } \\
\text { cient for stain- } \\
\text { less steel }\end{array}$ & Unknown \\
\hline
\end{tabular}




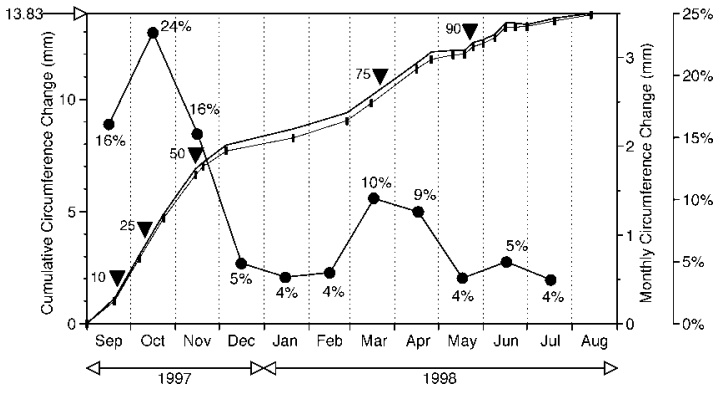

Figure 3. Example vernier band data, showing the raw growth curve, the correction for thermal expansion/contraction of the band, and derived monthly growth data. The thin line with small vertical blocks (measurement dates) is the cumulative growth of Tree 1013 over the 1997-1998 growing season (left scale). The thicker line is after correction for thermal expansion of the stainless steel band. Total circumference change was $13.83 \mathrm{~mm}$. Linear interpolation was used to calculate growth rates between measurement dates, from which monthly growth (dots, right scales) was derived. The percent of the total growth that occurred in each month is plotted against these points. Large triangles with numbers to the left indicate dates corresponding to $10,25,50,75$, and 90 percent of total growth. Note the ambiguity concerning the timing of growth termination.

cause of a higher thermal expansion coefficient and the fact that expansion and contraction of the sap may be accommodated by vertical flux. The bands would also be expected to have a greater diurnal change because of the thermal inertia of the trees. The expected net impact on recorded vernier measurements is systematic under-estimation of growth during warming periods (spring and summer) and over-estimation during cooling periods (autumn and winter). The vernier measurements were corrected for thermal expansion (Figure 3) using the thermal expansion coefficient for stainless steel $\left(1.6 \times 10^{-5} \mathrm{~mm} \mathrm{~mm}^{-1}{ }^{\circ} \mathrm{C}^{-1}\right)$ and the mean daily surface air temperature recorded at Auckland Airport for the observation day. Using these data assumes that the change in air temperature within the forest was similar to the change in air temperature at the airport (air temperature measurements within the forest through 1999 confirmed this). No correction was made for the thermal expansion/contraction of the trunk because there was no basis for estimating it. Correcting for only one source of thermal expansion/contraction error means there is a residual seasonal bias error of over-estimation of growth up to February and under-estimation subsequently. However, this is thought to probably be less than the error associated with making no correction at all.

\section{Verification of Vernier Band Data Using Short Cores}

From the perspective of tree-ring applications, the vernier band method of measuring tree growth is flawed in that it includes bark growth. To determine the relative contributions of wood and bark, and to verify the vernier results, multiple short increment cores (5-mm diameter) were extracted (Table 1). The within-growing-season cores in 2002-2003 were a mix of tree sizes. These data added a fourth year to the seasonal growth pattern analysis (albeit at much lower temporal resolution) and useful supplementary data. Because of poor circuit uniformity in kauri, at least three cores were taken on each sampling date, to capture ringwidth variability around the trunk, and the median was used as the measure of central tendency (because it is less sensitive to outliers than the mean).

Cores were air dried for about a week, glued into wooden mounts with tracheids orientated vertically, then sanded to a fine polish to reveal the ring structure. Ring widths were measured using a binocular microscope and traveling stage with an optical linear encoder, to a precision of $0.01 \mathrm{~mm}$. Measurements were scaled by $+2 \%$ to compensate for drying shrinkage, based on analysis (not shown) of an additional 36 cores taken in September 2004.

\section{Data Analysis}

Vernier band data for each tree, for each growing season, was processed to extract monthly growth rates by linear interpolation between observation dates (Figure 3). It was assumed that no growth occurred until September and that growth ceased by the end of July. Where the total seasonal growth was also known, fractional monthly circumference change (percentages in Figure 3) was also calculated to standardize results from trees with different growth rates.

Monthly data for all 43 trees were pooled and 
plotted for each growing season. The median was used as the primary statistic of central tendency and box-and-whiskers plots were used to represent inter-tree variance. The analysis was repeated for both the absolute and fractional growth rate data. These were compared to explore inter-relationships between absolute inter-tree variance and the stability of the relative contribution of each month to the total ring-width. Inter-annual comparisons were then made to determine if a generic seasonal growth pattern was evident.

To investigate if kauri's seasonal growth pattern is affected by tree size, the data set was split into three size-dependent cohorts (Table 1). The division between the small and medium size classes corresponds to physiological changes that occur in the roots and crown associated with change from kauri's conical juvenile form to its mature form of an emergent crown (Ecroyd 1982). The division between medium and large trees is more arbitrary, although a change in growth rates at about this time is suggested by the results presented by Ogden (1983). Each size cohort was then analyzed, as for pooled data, and the results compared.

We also calculated several statistics concerning the timing of tree growth that we related to tree size $(\mathrm{DBH})$. Five statistics related to the timing of tree growth were derived from the vernier cumulative growth data. These were the number of days since the end of August corresponding to $10 \%$, $25 \%, 50 \%, 75 \%$, and $90 \%$ of total growth for the growing season (D10, D25, D50, D75, D90) (Figure 3). Two further statistics were calculated from these to provide a measure of the temporal concentration of growth (D75-D25) and a surrogate for growing season length (D90-D10).

\section{VALIDITY AND LIMITATIONS OF THE VERNIER BAND DATA}

Comparison of the annual radial increments estimated from verniers with those derived from cores (Figure 4A) indicates generally good agreement. Both sets of data indicate substantial intertree but relatively minor inter-annual variance. For example, the $0.23 \mathrm{~mm}$ range in annual median radial increase for the verniers is less than one third of the inter-tree standard deviations (0.73-0.82 $\mathrm{mm})$. Consistency of inter-tree variance across years and between data sources is also noteworthy.

The main (expected) difference between the radial increments derived from verniers and cores is the $20-28 \%$ difference in the respective annual medians. This probably relates to a net increase in bark thickness and to cumulative lifting of the bark under the verniers. Some support for this contention is found in the positive relationship between tree size and the ratio of vernier to core radial measurements (Figure 4B-D). The ratios are close to one for small trees, but increase with tree size. The largest trees are the ones that shed bark in platesize fragments and where associated problems with vernier bands were observed. Assuming that the positive regression line slopes (Figure 4) are caused by bark flaking, the cluster of trees less than $0.4 \mathrm{~m} \mathrm{DBH}$ provide the best estimate for the relative proportions of wood and bark growth. This ratio is $4: 1$, averaged over the three growing seasons.

Although the above results indicate that we can have some confidence in estimates of the annual ring width derived from the vernier bands, it does not follow that intra-annual features in the growth curves are all meaningful, especially considering the plethora of potential errors (Table 2). From close inspection of the seasonal growth curves (e.g. Figure 3), in the context of these error sources, we draw four conclusions:

a) The error correction associated with thermal expansion of the vernier bands is relatively small. For example, the percentage of growth attributed to each month changes by no more than $1 \%$ if no thermal correction is applied. It follows that the error associated with not correcting for the smaller compensating thermal expansion of the trunk is minor.

b) Even putting aside the problems associated with pre-growth tissue swelling (Error 10), it is clearly impossible to even crudely ascertain the timing of growth initiation and cessation from vernier band data. It is quite plausible that the tree in Figure 3 stopped growing in May 1998 and that the continuing increase in circumference, through to August, relate to the bark swelling as it picked up moisture at the start of winter. 

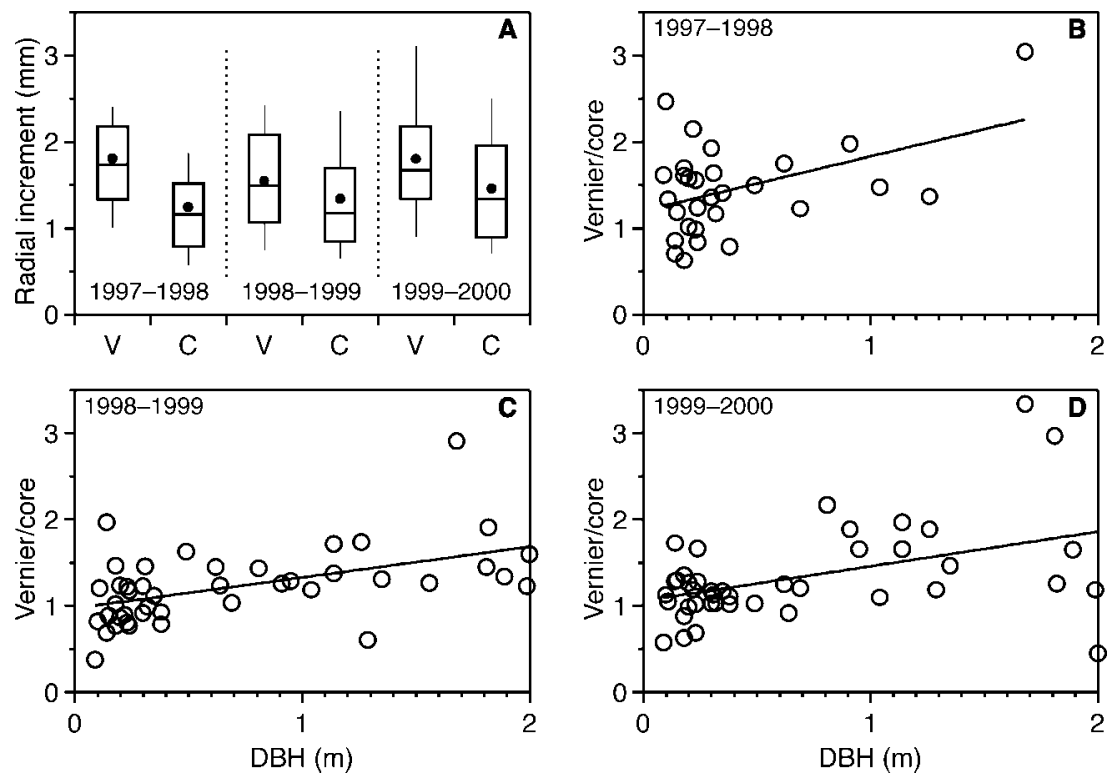

Figure 4. Comparison of annual radial increment derived from vernier bands ("V" in Panel A) and short cores ("C" in Panel A). Core measurements are ring-width measurements, scaled to account for shrinkage during sample preparation. Vernier band measurements include bark growth and cumulative errors associated with the band method. The box-and- whiskers plots indicate 10th, 25th, 50th, 75th, and 90th percentiles and the mean (dots). Panels B-D show ratios of vernier to core annual increments plotted against tree DBH.

c) High growth rates in spring are probably realistic, but possibly slightly exaggerated. Pregrowth tissue swelling (Error 10) means that some of the September circumference increases were unrelated to wood growth. Applying a thermal expansion correction to the vernier bands but not the trees also meant that spring growth was slightly exaggerated.

d) It is not possible to attribute cause to the very large decline in circumference growth rate over summer (DJF) because there is no basis for determining the relative contributions of growth reduction and water deficit shrinkage effects. For the same reasons, it is not possible to determine the relative contributions of growth and rehydration to the circumference increase rebound in March.

Our suspicion that circumference increases in September may not be related to wood growth was heightened by the fact that only one of the 12 trees cored on 24 September 2002 showed evidence of radial growth. This may indicate one, or a combination, of three things. First, there may have been a later start to growth in 2002 than was experienced during the period of vernier measurements. Second, the growth assigned to September mostly occurred towards the end of the month. Third, circumference expansion in September may have been pre-growth tissue swelling (Error 10 in Table 2). To further investigate the latter, additional short cores from 12 trees were taken on 21 September 2004. Of these, only three small trees (0.20-0.24 m DBH), growing in relatively sunny positions, had new xylem cells. Although definitive conclusions are not possible (because the vernier and increment core data are for different years), on balance it seems likely that most of the recorded circumference increases in September relate to pre-growth tissue swelling, rather than $\mathrm{xy}$ lem formation.

\section{KAURI ANNUAL GROWTH CHARACTERISTICS DERIVED FROM POOLED DATA}

The most striking result emerging from the monthly analysis of pooled data is the dominance 
of spring growth (Figure 5). For all three complete growing seasons, October and November were the first and second ranked (collective) growth months, accounting for over $38 \%$ of the total growth season increment of most trees, and over $50 \%$ in 1999-2000. Because of the spring dominance, most trees had completed over $60 \%$ of their total growth by the end of December. October and November are also noteworthy in terms of exhibiting the greatest inter-annual variability. The median circumference change of $5.2 \mathrm{~mm}$ for these two months in 1999 was $29-35 \%$ greater than that recorded in $1997(4.0 \mathrm{~mm})$ and $1998(4.2 \mathrm{~mm})$.

There was a decline in monthly growth rates from early summer (December) through to early winter (June). The immediate decline from the spring peak was gradual in the case of 1997-1998, but a more abrupt 50\% decrease from November to December for the other two years. Minimum growth rates were recorded in autumn, although timing varied. Many trees had a growth-rate rebound in mid- to late-autumn (April-May). This was most pronounced in the case of April 2000. Growth was near-zero in July, except in 1998. The latter hints at a delayed end to the growing season. Post-summer growth accounted for no more than $20 \%$ of the growing season total.

In general, high (low) inter-tree variance was coupled with high (low) growth rates. For example, the three months with the largest growth rates $(10 / 1999,10 / 1998,11 / 1999)$ also had high variance, and low growth rates late in all three growing seasons were coupled with low variance, especially in June and July. In contrast, although inter-annual variation in September median growth was small $(0.92-1.11 \mathrm{~mm})$, there was significant inter-tree variance, which presumably indicates considerable variability in tree response to early growing season environmental conditions.

The fractional growth rate plots (Figure 5C, E, G) show reduced inter-tree variance compared to their absolute growth rate equivalents for all months except November 1998. For example, in the case of October 1998, whereas there was an $85 \%$ difference between the absolute growth rates corresponding to the 75th and 25th percentiles, there was only a $42 \%$ difference in the case of fractional growth. The difference was even more pronounced $(217 \%, 70 \%)$ for the 90th and 10th percentiles. This indicates that even though trees may be highly varied in their absolute growth rates for a given month, they are markedly more consistent in terms of the proportion of the total ring laid down in that month.

In addition to the commonalities in the monthly growth-rate data emphasized above, we also found several notable differences. The most obvious of these is the different spring through summer transition in 1997-1998, previously noted. Although growth rates in October and November were similar to those in 1998-1999, inter-tree variance was relatively low and the gradual decline in median growth through summer (DJF) contrasts with the abrupt November to December transitions in the other two years. However, it is noteworthy that December and January (1997-1998) both showed large inter-tree variations. It appears that, although some trees maintained relatively high growth rates, others may have been finding conditions more difficult. There were similar situations of anomalously high inter-tree variance in March 1998 and April 1999.

The plots of combined medians (Figure 5H, I) reinforce the general consistency in the growth response pattern emphasized above, but also the implications of some of the nuances. For example, although the absolute October and November growth rates were almost identical for the 19971998 and 1998-1999 seasons (Figure 5H), the relative contributions to total growth were lower in 1997-1998. This is because of the contributions of December and January (1997-1998) growth, which resulted in greater total growth and therefore reduced the relative contribution of October and November. It is also noteworthy that the significantly higher absolute growth rates in October and November 1999 transformed to more subdued differences (compared to 1998-1999) in fractional contributions to total growth. This is because the total growth for 1999-2000 was higher than 19981999 , making the relative contribution of spring growth quite similar.

Results from analysis of the short cores taken during the 2002-2003 growing season were consistent with those reported above for the vernier bands. Spring growth was again dominant and the 

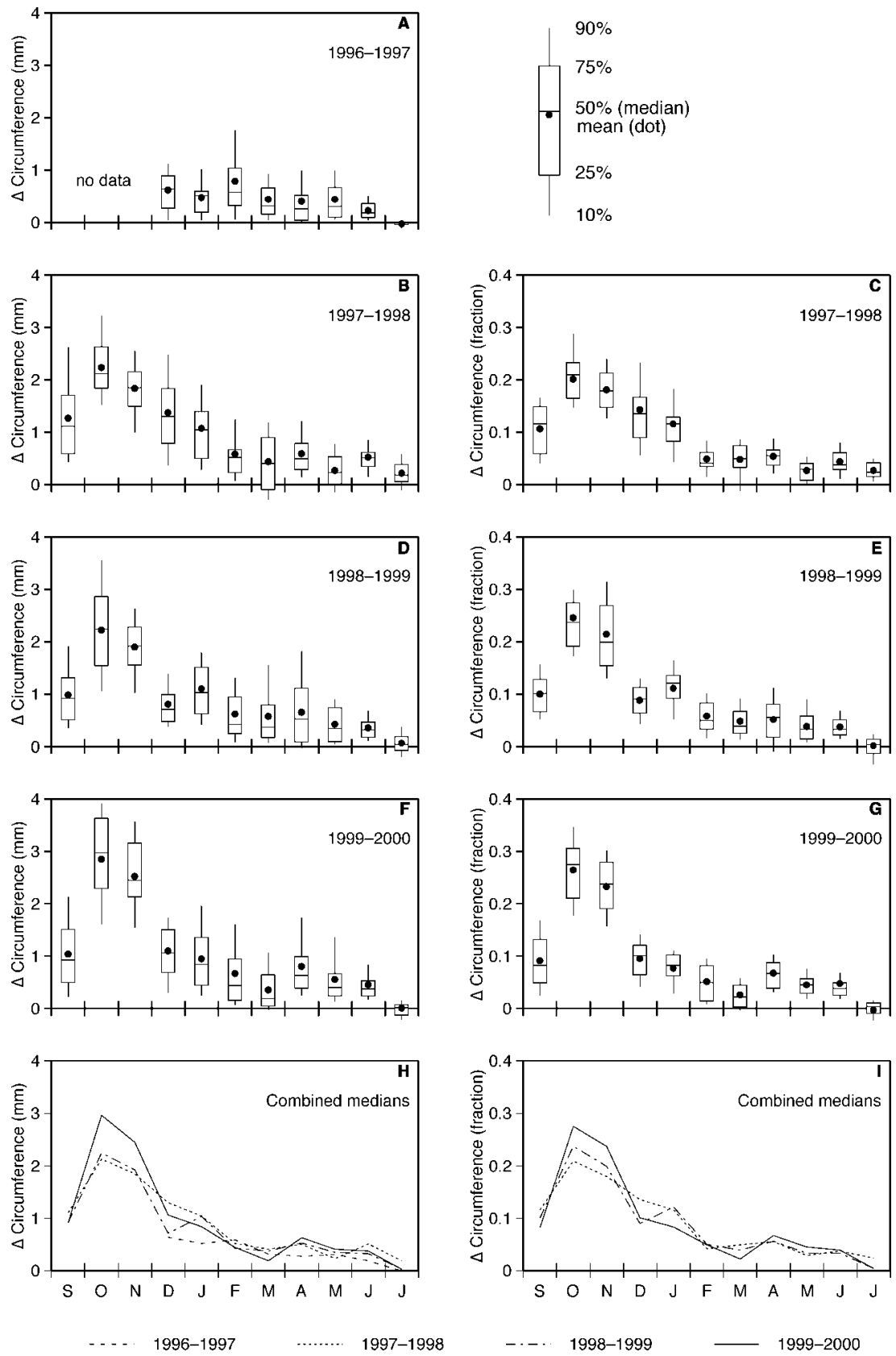

Figure 5. Inter-tree and inter-annual variations in absolute (left panels) and fractional (right panels) monthly circumference changes. Fractional growth is not available for 1996-1997 because of incomplete data and the fractional plot for 1997-1998 (Panel C) is based on a reduced data set (see text for details). Inter-tree variance is represented by the box-and-whiskers plots. The bottom two panels plot the medians from the panels above them to assist inter-annual comparison. 

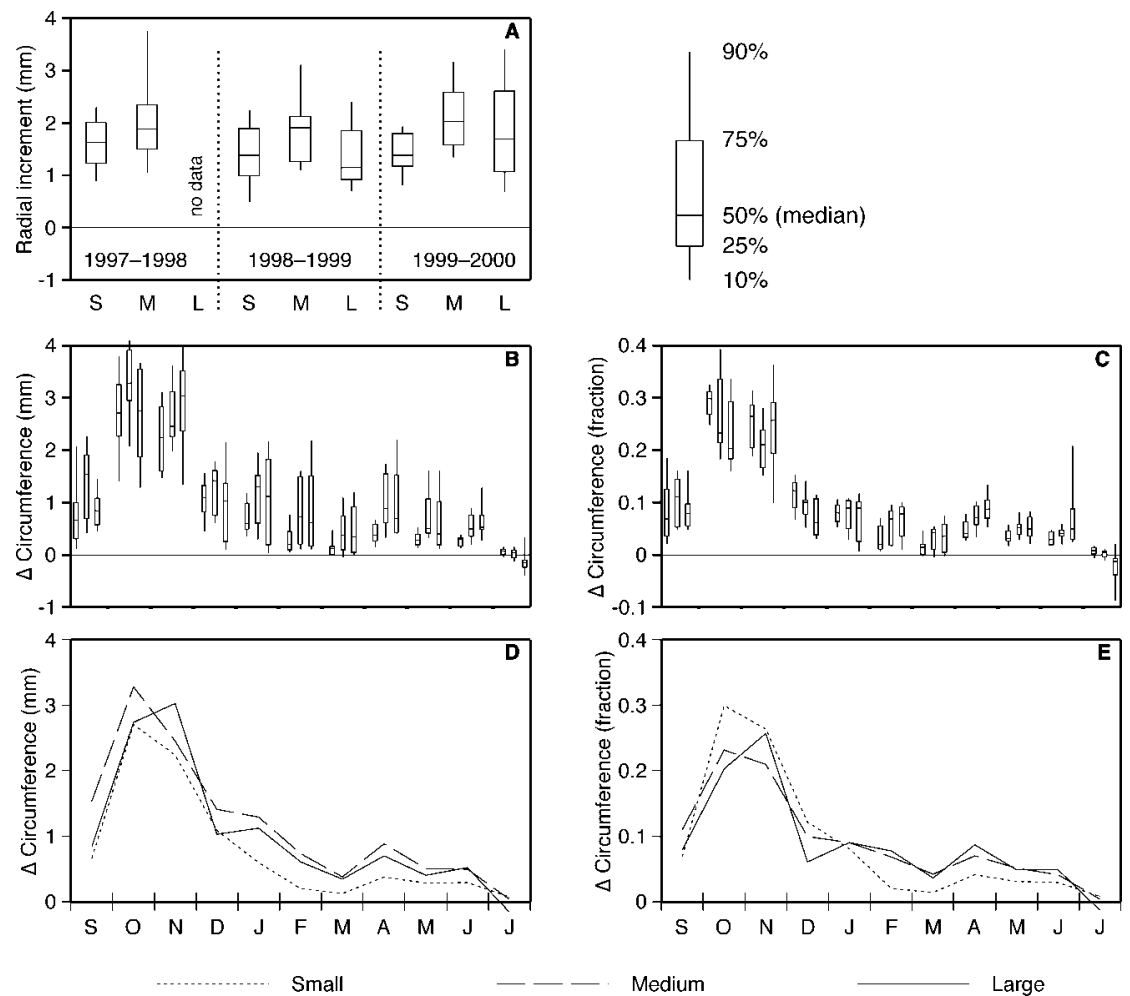

Figure 6. Dependence of annual and monthly growth rates on tree size. Panel A separates vernier annual radial increment results presented in Figure 4A, for small (S), medium (M), and large (L) trees. Panels B and C are a similar size class breakdown of the results for the 1999-2000 season presented in Figures 5F and 5G. Panels D and E plot the medians for each size class (from Panels B and C).

trees experienced a similar late-season growth dip, followed by a rebound. The fact that the latter was present in the (dry) ring widths indicates that this feature is probably at least partially related to changes in growth rates, rather than being simply trunk shrinkage and expansion in response to water availability.

\section{DEPENDENCE OF ANNUAL GROWTH CHARACTERISTICS ON TREE SIZE}

\section{Size Cohort Analysis}

The specific purpose of the cohort analysis was to undertake more detailed study of some of the results presented in the preceding section. A critical question, from a uniformitarianism perspective, was whether the spring-time growth dominance was common to trees of all sizes and consistent in strength. We also wanted to know wheth- er high variance months identified in the pooled data were caused by different sized trees behaving differently. Similarly, was apparent autumn growth rebound limited to large trees (consistent with a rehydration rather than a growth spurt hypothesis)? The analysis results are:

a) Spring-time growth dominance was common to all three size cohorts, but a difference in the timing of peak response within spring was apparent. Small and middle-sized trees experienced their peak absolute and relative growth rates in October, compared to a November peak for large trees. This pattern was consistent over all three years.

b) The median growth rate of middle-sized trees was consistently greater than the other two cohorts, both for annual ring-width (Figure 6A) and for $64-82 \%$ of individual months (depending on growing season). The difference was 
most pronounced in September and October, with 1999 the least extreme case (Figure 6B). Middle-sized trees were also consistently the fastest growing from March to the end of the growing season.

c) High variance months identified in the pooled analysis were characterized by high inter-cohort variability. In most cases one of the three cohorts was notably different from the others, but which cohort was "responsible" varied.

d) No clear picture emerged regarding the apparent autumn growth rebound question. Small trees were least affected, but middle-sized and large trees had inter-annual inconsistencies.

e) Inter-cohort differences were much more pronounced in the case of absolute than fractional growth rates (November 1998 is the only exception to this). For example, the high September and October growth rates of middle-sized trees were suppressed in fractional terms (Figure 6B, C). Indeed in October 1999, the smaller trees put on fractionally more of their growth than the faster growing middle-sized trees.

f) Large trees only had a few months when more than $25 \%$ of the trees had negative circumference change (each July; March and May, 1998; April, 1999). The July changes followed elevated positive circumference changes in June, but the absolute amounts were very small in both cases.

g) The 1999-2000 growing season differed somewhat from the previous two seasons in two ways. First, the growth rate of small trees was notably lower than the other trees in the latter half of the growing season (Figure 6D), by more than a factor of two in January, February, and March. Second, compared to the other two growing seasons, the intra-cohort variance for large trees was large for absolute circumference change from October 1999 to May 2000 (Figure 6B), especially in summer (DJF). However, the fact that fractional variance was suppressed (Figure 6C) indicates that some trees were doing consistently better/worse than others throughout the growing season. This is confirmed by the high variance for large trees for the 1999-2000 ring (Figure 6A).

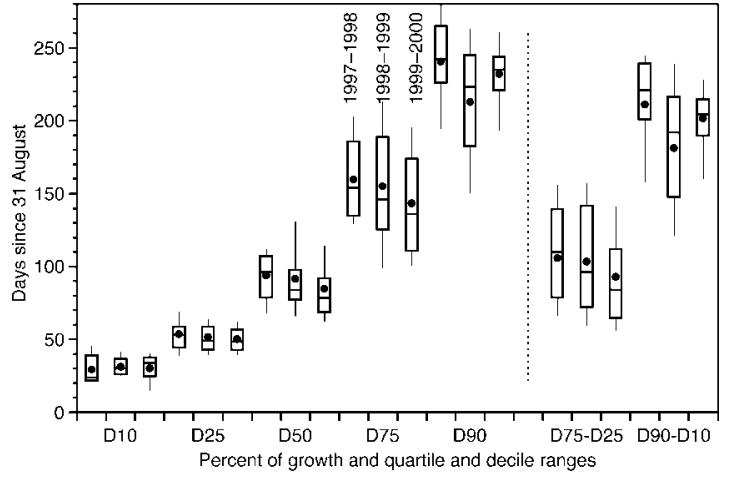

Figure 7. Inter-tree variation in the timing of seasonal growth, by size class. D10, D25, D50, D75, D90, D75-D25, and D90D10 are seasonal timing variables described in the text. The sets of three box-and-whiskers plots associated with each of these are for the growing seasons 1997-1998, 1998-1999, and 1999-2000, in the order indicated for D75.

\section{Analysis of Growth Timing Characteristics}

Pooled data analysis (Figure 7) indicates intertree and inter-annual consistency in the timing of the first half of the growing season (D10, D25, D50). For example, each year, most trees completed $10 \%$ of their growth within 11-18 days of each other, and variation in timing across the three years was 11 days (for the median tree). Given that D10 is being used here as a surrogate for the start of the growing season, this consistency is noteworthy, especially because it indicates that the relatively high growth year of 1999-2000 did not have an early start to growth. The consistency in the timing of growth continued for 3-4 months, with most trees having completed half of their growth within an 18-day period (17 Nov to $5 \mathrm{Dec}$ ), 79-96 days after the end of winter.

The timing of the second half of the growing season was much more variable. Inter-tree variations in timing for D75 and D90 were about twice as large as D50 and inter-annual variation was also larger (especially D90). Moreover, because of the contrast in early- versus late-season variation in timing, the quartile (D75-D25) and decile ranges (D90-D10) were effectively determined by the variation in timing associated with D75 and D90. Thus, the temporal concentration of the middle half of kauri growth was determined by late- rather than early-season variations. Similarly, the results suggest that the length of the growing season was 
Table 3. Correlation between growth timing statistics (D10 to D90-D10) and tree size (DBH). Statistically significant correlations $(p \leq 0.05)$ are italicized.

\begin{tabular}{lccc}
\hline \multirow{2}{*}{$\begin{array}{c}\text { Growth } \\
\text { Timing }\end{array}$} & \multicolumn{3}{c}{ Correlation for Growing Season: } \\
\cline { 2 - 4 } Statistic & $1997-1998$ & $1998-1999$ & $1999-2000$ \\
\hline D10 & -0.01 & 0.05 & 0.00 \\
D25 & -0.15 & 0.03 & 0.18 \\
D50 & 0.00 & 0.08 & 0.36 \\
D75 & 0.09 & -0.04 & 0.35 \\
D90 & 0.38 & 0.01 & 0.29 \\
D75-D25 & 0.13 & -0.05 & 0.34 \\
D90-D10 & 0.32 & 0.01 & 0.26 \\
\hline
\end{tabular}

determined more by variation in when growth ended, than by variability in the breaking of winter dormancy. Interestingly, most inter-tree variance was associated with D75-D25, with about a factor of two difference in the time taken to lay down the middle half of growth for the upper and lower quarter of trees.

A key question emerging from these results is the extent to which the high inter-tree variation in the timing of the late growing season is related to tree size. To investigate this, we examined the relationship between tree size and each of the seven growth timing statistics. Our interest was in D75 and D90, for the reasons noted previously, but the results for the other five statistics are presented for completeness. Scatter plots (not shown) for each of the seven statistics plotted against DBH were produced for each growing season. No non-linear relationships were apparent, so we adopted the linear correlation coefficients (Table 3 ) as appropriate measures of the strength and direction of relationships. These indicate generally weak relationships that are also inconsistent between years.

Inspection of the scatter plots and the correlation coefficients provides no evidence that the timing of the start of the growing season was significantly influenced by tree size. Neither did tree size appear to affect the timing of the first half of seasonal growth. We found some weak evidence that tree size may have some influence on the timing of the latter half of the growing season in 1997-1998 and 1999-2000. The correlation coefficients are all positive for D75, D90, and for the quartile and decile ranges and half of them are statistically significant ( $\mathrm{p} \leq 0.05$ ), suggesting a longer growing season for larger trees. However, the weakness of the relationships and their absence in 1998-1999, when inter-tree variance is greatest, leads us to conclude that any size-related influence on the timing of kauri growth is probably minor and that other explanations for inter-tree variance need to be sought.

\section{DISCUSSION AND CONCLUSIONS}

The most important result emerging from the analyses presented in this paper is the generic growth pattern for kauri (Figure 5). Consistent elements of the pattern include: the dominance of springtime growth; minimum growth in autumn, typically followed by a minor rebound; and slow growth, accompanied by low variance, at the end of the season. However, although these patterns are common at Huapai over the three complete growing seasons investigated, they only partially agree with a previous single season study of kauri growth (Palmer and Ogden 1983). They monitored kauri growth using similar vernier bands during the 1980-1981 growing season at three higher elevation sites (Konini Forks, 335 m; Mt. Moehau $1,810 \mathrm{~m}$; Mt. Moehau 2,450 m). Within the limits of vernier bands, the apparent timing of the growing season is similar to Huapai, but only the two lower elevation sites exhibited the autumn minimum then growth rebound. Significantly, Palmer and Ogden (1983) identified peak growth in latespring to mid-summer at all sites, notably later than the mid- to late-spring result for Huapai.

It is possible that the differences in the timing of peak growth between the two studies may partly relate to unmeasured springtime growth in the Palmer and Ogden (1983) study, as their verniers, installed in winter, took up the slack (a less significant problem in the Huapai case because the verniers were more flexible and, in most cases, were installed the previous year). Alternatively, we may be seeing real differences in seasonal growth characteristics, associated with different environmental conditions. For example, the three Palmer and Ogden (1983) sites are 245-720 m higher elevation than Huapai. A delay in the timing of peak growth could conceivably reflect the influence of 
altitude in delaying the timing of suitable temperatures for peak growth, although the similarity of peak growth timing across the Palmer and Ogden sites does not support this argument. Other possibilities are that conditions in summer differed in some critical manner from the three years corresponding to the Huapai study, or that phenological factors exist that diverted resources away from wood growth. At this stage, we cannot explain the differences between the two studies.

Spring growth dominance, combined with the fact that October and November growth rates also show the greatest inter-annual variation, suggests that environmental conditions affecting spring growth are most likely to influence the width of the annual ring, and therefore have the greatest potential for reconstruction from kauri tree rings. Conversely, the low growth rates and low variance near the end of the growing season indicate reduced reconstruction potential. These results are consistent with, and are highly informative in explaining, the results of Fowler et al. (2000). Fowler et al. identified stronger correlations between kauri tree rings and the Southern Oscillation Index than with local precipitation and surface air temperature, with correlations peaking in spring, then declining through the rest of the growing season. It seems highly likely that this results from a fortuitous coincidence of:

a) the strongest teleconnection patterns between ENSO and the climate of northern New Zealand occurring in spring (Gordon 1986, Mullan 1995), and

b) the dominant contribution of spring growth to kauri tree rings.

An important feature of our analyses has been the evidence of considerable inter-tree variance in both total seasonal growth (Figure 4A) and monthly growth rates (Figure 5). Several of the analyses were directed at investigating the extent to which this variance was associated with tree size. Our primary concern here was with the validity of the uniformitarianism assumption underpinning subsequent climate reconstruction work. If the character of kauri growth is dependent on the size of the tree, then the climate signal carried in the annual ring may vary with tree size, perhaps neces- sitating the truncation of tree-ring time series to remove sections when trees were young. Our results were mixed.

From this uniformitarianism perspective, we note two particularly encouraging results. First, all three size cohorts exhibited a spring growth peak. Second, the relative proportion of growth occurring in each month was similar for the three age cohorts, even though absolute growth rates showed a strong association with tree size. It follows that there is similar potential for a given climate anomaly to register in kauri ring widths, regardless of tree size. This does not imply that tree response to an anomaly will be the same because associated size-related differences in factors such as rooting depth and position of the crown in the canopy are likely to influence tree response. However, if the timing of peak growth was different, or accounted for significantly different proportions of growth, we may need to contend with quite different climate signals preserved in the tree rings. We note though that the November peak for large trees ( $\geq 1.1 \mathrm{~m} \mathrm{DBH}$ ), compared to October for smaller trees, may be important in this regard.

Analysis of growth timing characteristics in relation to tree size was also encouraging from a uniformitarianism perspective as a consistent early season growth pattern was identified that extends through the spring peak growth period. We found some suggestion that growth timing variations in the second half of the season may be related to tree size, but relationships were weak and inconsistent between years.

Less encouraging is evidence that high inter-tree variance in growth rates tend to be associated with inter-cohort differences. This suggests that different-size trees are collectively responding somewhat differently to evolving climate conditions through the growing season. Moreover, even from the three seasons analyzed, we found examples of inter-annual variance in the growth response that appear to relate to size, such as the low growth rate of small trees $(<0.3 \mathrm{~m} \mathrm{DBH})$ in 2000 (Figure 6 ). Based on these findings and the previously noted differences in the timing of peak spring growth, some residual doubt remains concerning the appropriateness of incorporating material from small trees when constructing tree-ring chronologies for 
climate reconstruction purposes. Further research is required to pursue this, including analysis to determine if differences exist in the statistical relationships between tree rings and climate that relate to tree size.

An important caveat needs to be attached to the results and conclusions pertaining to tree size. Because of the distribution of kauri at Huapai, splitting the sample into groups based on tree size is also effectively a split on location. For example, all of the small trees are located at the northern end of the eastern ridge, and almost all the large trees are on the western ridge. Consequently, any influences of tree size on the seasonal growth pattern are confounded with environmental factors, potentially resulting in a misinterpretation of the significance of tree size. To our knowledge there are no significant environmental differences, but these have not been explicitly investigated.

The analyses undertaken in this study compared the statistics of pooled data or subsets for periods no finer than monthly. Some evidence has emerged of tree-size related variability in growth response (e.g. large trees peaking in November rather than October), but the vernier data are not conducive to probing deeper. For example, we cannot resolve if the October-November difference was caused by subtle changes in timing of peak growth in late October and early November, or to fundamental differences in growth pattern, such as differences of many weeks. Although to some extent our analysis is limited by the temporal resolution of data collection, it is unlikely that much more information could have been gleaned from more frequent observations, because of the numerous sources of error associated with vernier observations. Answering such specific and detailed questions will probably require alternative methods aimed at high resolution observations, such as loggable point dendrometers or sap flow monitoring.

Finally, it is noteworthy that, although this study has demonstrated high inter-tree variance in growth rates, it has not identified the mechanisms underpinning that variance. Having selected trees to obtain a diverse range of sizes, we expected to find high inter-tree variance, but were surprised to find that size explained relatively little of it. If most variance is unexplained, it follows that other causal factors are probably important, such as treespecific characteristics (canopy form and exposure, disease, injury, etc.) and site characteristics (soil drainage, slope, aspect, etc.). Further investigation would be helpful in terms of informing climate reconstruction. For example, if soil wetness was found to be an important factor, this would raise critical uniformitarianism issues because multimillennial climate reconstruction from kauri tree rings may assume that transfer functions derived for modern trees, predominantly growing on welldrained ridges, are applicable to sub-fossil samples that grew adjacent to, or on, bogs.

\section{ACKNOWLEDGMENTS}

Financial support for this research was provided by the New Zealand Foundation for Research, Science and Technology (FRST contract UOAX0011) and by the Royal Society of New Zealand (Marsden Fund grant UOA108). Gretel Boswijk and Joelle Gergis provided invaluable field assistance. Two anonymous reviewers and an Associate Editor provided helpful guidance that improved the quality of this paper.

\section{REFERENCES CITED}

Buckley, B., J. Ogden, J. Palmer, A. Fowler, and J. Salinger

2000 Dendroclimatic interpretation of tree-rings in Agathis australis (kauri). 1. Climate correlation functions and master chronology. Journal of the Royal Society of New Zealand 30:263-275.

Ecroyd, C. E.

1982 Biological flora of New Zealand, 8. Agathis australis (D. Don) Lindl. (Araucariaceae) Kauri. New Zealand Journal of Botany 20:17-36.

Fowler, A.

1984 A Dendroclimatological Study of Kauri (Agathis australis). Unpublished MA thesis, University of Auckland, Auckland.

Fowler, A.

1999 Potential climate change impacts on water resources in the Auckland Region (New Zealand). Climate Research 11:221-245.

Fowler, A., and G. Boswijk

2001 Tree-ring analysis of kauri (Agathis australis) from Huapai Scientific Reserve, Huapai, Auckland. New Zealand Tree-Ring Site Report No. 6. University of 
Auckland, Department of Geography Working Paper No. 13 (ISBN 0-908672-91-8).

Fowler, A., G. Boswijk, and J. Ogden

2004 Tree-ring studies on Agathis australis (kauri): a synthesis of development work on Late Holocene chronologies. Tree-Ring Research 60:15-29.

Fowler, A., J. Palmer, J. Salinger, and J. Ogden

2000 Dendroclimatic interpretation of tree-rings in Agathis australis (kauri): 2. Evidence of a significant relationship with ENSO. Journal of the Royal Society of New Zealand 30:277-292.

Fritts, H. C.

1976 Tree Rings and Climate, Academic Press, New York. Gordon, N. D.

1986 The Southern Oscillation and New Zealand weather. Monthly Weather Review 114:371-387.
Mullan, A. B.

1995 On the linearity and stability of Southern Oscillationclimate relationships for New Zealand. International Journal of Climatology 15:1365-1386.

Ogden, J.

1983 The scientific reserves of Auckland University. II. Quantitative vegetation studies. Tane 29:163-180.

Palmer, J., and J. Ogden

1983 A dendrometer band study of the seasonal pattern of radial increment in kauri (Agathis australis). New Zealand Journal of Botany 21:121-126.

Schweingruber, F. H.

1996 Tree Rings and Environment: Dendroecology. Haupt, Berne.

Received 26 October 2004; accepted 28 February 2005. 